\title{
2 \\ The decline of the classical model of military strategy
}

\author{
Lawrence Freedman
}

The classical model of military strategy, as described by the great theorists of the Napoleonic War, is the one to which contemporary strategists still aspire. It described how wars should be fought and so is best described as an ideal type in that it has always been understood that it would be difficult to realise this model in practice. According to this model, political objectives are achieved when enemy forces are no longer able to fight, preferably because they have been defeated in a decisive battle. Long wars can be accommodated in the classical model, but the best strategy offers a route to quick victory at tolerable cost. The essential feature is that warfare involves regular forces pitted against each other. Wars can be won by inspired commanders exploiting their strengths and the enemy's weaknesses almost independently of the underlying material strengths of the belligerent states. In its original form, this model involved two vital conventions: first, that non-combatants must be kept out of the frame; and second, that governments must accept the result of the fighting. Political gains would follow naturally from military gains.

The first of these conventions had been completely lost by the time of World War II. The non-combatant category had almost lost meaning as volunteers engaged in guerrilla warfare against an occupying army and populations came to be seen as legitimate targets either because by their everyday work they were supporting the war effort or else their 
subjugation was a war aim in itself. Yet the second convention still held. In the end, both World Wars I and II were decided as a result of a series of battles, their conclusions being marked by the surrender of the armies of one side to the other. But these were not wars that had been won so much by brilliantly conceived military operations as by the remorseless application of superior resources. In a book entitled The Revolution in Warfare, completed just as the Pacific War was concluded, the British strategist Basil Liddell Hart lamented the transformation of war 'from a fight to a process of destruction'. ${ }^{1}$

The idea of a military sphere with its own rules and conventions, which could be kept separate from a more innocent and safe civilian sphere, appeared to have been forever lost. All the history of that deadly century warned that battle would keep on bursting out of past boundaries, uncontainable in space or time, with civilians caught in the centre of the frame rather than kept safe at the margins. Technology had pushed states to total war as ever more sophisticated means were found to slaughter people on a large scale. Future conflict promised to be even more destructive. Even without atom bombs, centres of civilian population were still subjected to air raids during the Korean War. In the 1950s, there were successful tests of multi-megaton, city-busting, thermonuclear weapons.

In these circumstances, it was hard to expect that a war could take the form of a succession of battles leading to a military victory, as opposed to an escalating process of ever more horrendous devastation leading to mutual annihilation. The theorists of deterrence concluded that the only way to manage the situation was to embrace and then manage the destructiveness of modern weaponry. This required putting aside any thought of a nuclear battle with a clear victory. Once it was assumed that one side was preparing to fight a nuclear war, the assumption itself could result in massive instability and a catastrophe that might otherwise be avoided. Nonetheless, possible routes to a nuclear victory were still explored in think tanks and on military staffs, as if this might be possible if the right weapons were developed and deployed in the most effective way so as to disarm the enemy in a pre-emptive strike.

1 Basil Liddell Hart, The Revolution in Warfare, Faber, London, 1946, p. 33. 
The possibility of pre-emption was a natural concern for the United States as a result of Pearl Harbor. The fear of a bolt from the blue that would take out its most vital nuclear assets and leave them without any means of retaliation was given credibility in studies undertaken at RAND by a team led by Albert Wohlstetter. In 1954, its members demonstrated how the United States might be caught out with a pre-emptive strike by a calculating Soviet Union. This was not well received by RAND's client, the US Air Force's Strategic Air Command (USAF SAC). They considered it unrealistic in its modelling of a Soviet strike and unfortunate in suggesting that SAC needed to put effort into ensuring the survival of its own bombers rather than gear up for its own first strike. Wohlstetter considered SAC dangerously complacent and set about campaigning to have the vulnerability problem recognised. He lobbied in Washington, gave numerous briefings and went public with his anxieties. In an influential article on 'The Delicate Balance of Terror', he warned against assuming that just because both sides were acquiring sizeable stocks of weapons, the situation was becoming stable. Instead, he argued that stability would depend on many factors such as the range, yield and accuracy of weapons and the hardness and mobility of targets, along with issues of warning and sequencing. ${ }^{2}$

This approach encouraged the view that the stability of the nuclear balance could be known for sure only through complex calculations. It was not enough to assume that the possibility of mutual annihilation would scare political leaders away from rash actions. Both sides were seeking out advantage in new technologies, and the concern in the United States was that the Soviet Union was moving ahead in this race. Not only had it tested the first intercontinental ballistic missile, but also it had launched, in October 1957, the world's first artificial earth satellite: Sputnik 1. In the event, the US missile program was more successful than the Soviet Union's. Nevertheless, in Washington there was little confidence that a successful first strike could be launched without it turning out to be catastrophic and suicidal. By the mid-1960s, it was accepted that the prevailing condition was one of 'mutual assured destruction'.

Now that it was accepted, fatalistically, that any war would probably 'go nuclear' almost immediately, the major powers were scared into caution. This was not the result of complex analyses of the balance but

2 Albert Wohlstetter, 'The delicate balance of terror', Foreign Affairs, January, 1959, pp. 211-34. 
the smallest of risks of becoming involved in a nuclear exchange. Their nuclear arsenals were prepared for war, but their main function was to serve as a reminder that however deep the antagonism they should not let any disputes get out of hand. Wars had to be deterred, not fought. This left the task of designing, constructing and sustaining conventional armed forces extremely difficult. The word 'conventional' suggested some link with the past 'conventions' of classical warfare, but there was no obvious route to a decisive battlefield victory against a nuclear-armed opponent. Preparations for conventional war did not necessarily assume that a nuclear war could be avoided. Instead, the aim was to reinforce deterrence, for only an all-out conventional war was likely to create the conditions that could potentially bring about Armageddon. As a cold decision, a nuclear strike appeared irrational, but one that became more credible as something more emotional and hot-headed, taken in the fever of war, with casualties already accumulating and land torn apart as great offensives were launched and resisted.

A slightly more congenial possibility was that a defensive line might be held, or an enemy's advance made costly and painful, thereby allowing sufficient time for second thoughts and active negotiations, hopefully interrupting the nuclear powder trail before it reached its explosive climax.

The Americans were always deeply uncomfortable with this state of affairs. They were unnerved by the possibility of a war in Europe putting their homeland so directly at risk if matters escalated to nuclear exchanges and worried that if they made their anxiety on this matter too evident they would undermine the credibility of the deterrent and so help to create the situation they were desperate to avoid. From the early 1960s, they therefore began to press the Europeans to improve conventional forces so that at least there was no need to rush into the dire choice of suicide or surrender in the event of sudden aggression. While it might have been the case that the prospect of nuclear war ensured caution at time of crisis, this was not something upon which the Americans wished to rely. They worked to separate the nuclear from the conventional, with a firebreak between the two, and to encourage the North Atlantic Treaty Organization (NATO) to build up its conventional forces.

Eventually, in 1967, the doctrine of 'flexible response' was adopted whereby the Europeans recognised the US requirement for an extended conventional stage so that the first shots across the Iron Curtain would 
not lead automatically to a nuclear holocaust. In return, the United States accepted the need for a clear link between a land war in Europe and its own strategic nuclear arsenal.

By this time, the work was underway that would result in the transformation of conventional warfare. The most impressive development lay in the improved accuracy of modern weaponry. 'Smart' bombs were first employed during the USAF's Linebacker campaigns in the closing stages of US military involvement in the Vietnam War. Whereas once it might have taken numerous sorties for an important bridge to be destroyed, now this could be achieved with a single weapon. The success of air defence and anti-tank weapons during the opening stages of the October 1973 ArabIsraeli War encouraged confidence that the trend could include moving as well as fixed targets. Over time, the same accuracies could be achieved over ever-extending ranges and against a moving target, so long as it was in the open. With increasingly intrusive sensors it was also becoming possible to work out where enemy forces were and what they were up to. They could then be hit with a high probability of success. Liddell Hart had concluded in 1945 that the rot had set in to modern warfare when it was realised that air raids could not be used to hit specific military targets but instead only large civilian areas. 'Inaccuracy of weapon-aim resulted in inhumanity of war-aim. ${ }^{3}$ The corollary of this was that, if bomb aim was more accurate, so too could be war aim. War could become more of a fight. The trend away from decisive battle might at last be reversed.

But quick victories had proved to be elusive well before the nuclear age. If a war could not be won quickly then it tended to drag on with the advantages moving to those with the greatest financial, industrial and demographic strength — and therefore durability. The early evidence was that the new technologies would not necessarily support conventional offensives. The greatest beneficiaries of improvements in accuracy and lethality appeared to be defensive weapons, whether firing against aircraft, tanks or warships, so that future blitzkriegs would be even harder to execute. Anything in range and out in the open was vulnerable.

If frontal assaults were hazardous, then manoeuvrability appeared to be the best way to get around strong defensive positions. From their study of Warsaw Pact exercises and military literature, NATO planners concluded that their adversaries had put a lot of effort into developing armoured 
divisions and plans for moving fast to outflank NATO defences. ${ }^{4}$ This led to pressure for NATO to start preparing along the same lines, improving mobility to match that of the Warsaw Pact. Much more fluid and complex battles were envisaged. Their conduct would be facilitated not only by precise weaponry but also by improved means of intelligence-gathering, surveillance, command, control and communications. In this way, the digital revolution would make itself felt. A return to the classical model now seemed possible.

Eventually, in the GulfWar of 1991, the possibilities of the new technologies were revealed, albeit not against the Warsaw Pact but instead against a much weaker opponent that had adopted Soviet weaponry and tactics. The US-led coalition was able to fight an essentially classical conventional campaign to a swift and decisive conclusion and with limited casualties (especially on the coalition side). Here was a demonstration of the advantages American commanders enjoyed as a result of improvements in sensors, data management and communications as well as accuracy, so that Iraqi units were left stranded and picked off with ease while cruise missiles arrived at individual targets in the middle of built-up areas and destroyed them with minimal damage to any other buildings in the vicinity. The Iraqi military was swiftly rendered blind, deaf and dumb. Although the new capabilities were not quite as effective as some of the initial propaganda suggested, it did not take very much imagination to see how this form of warfare could be taken further. A rosy future for the US armed forces was at hand in which they might expect to be completely dominant. The combination of precision guidance and the new information technologies led to talk in the early 1990s of a 'revolution in military affairs' (RMA).

As the technology became even smarter, so the choices became sharper. Picking targets moved on from large military formations to specific units and then on to particular facilities - even in the middle of civilian areasand eventually, by this century, designated individuals. Unmanned drones controlled from a distance can now hover over an area, identify targets and, on command, attack them. The cumulative impact of all these developments has had a profound influence on Western military thinking.

4 Johan Holst and Uwe Nerlich (eds), Beyond Nuclear Deterrence: New Aims, New Arms, Crane Russak, New York, 1977.

5 See Lawrence Freedman, Strategy: A History, Oxford University Press, Oxford and New York, 2013, Chapter 16. 
Despite the fact that the new weaponry was employed against much weaker forces unable to fight back in kind, its successes encouraged the view that war in general could be turned away from its assumed totality and destructiveness. It raised the possibility of getting away from massive destruction and back to the classical view of war as a contest between regular forces acting apart from society. It has become possible to think again of non-combatant immunity as a real value. This was reinforced by the view, first developed as a result of the surveys conducted after World War II's massive bombing campaigns, that societies absorbed punishment in preference to surrendering and, if innocents were killed, then populations would be turned against the perpetrators. Consequently, a vicious and uncontained approach to war would be not only reprehensible but also counter-productive. With new technologies, large-scale killing need no longer be tolerated as an unavoidable consequence of war. Instead, the focus could be on disabling an enemy's military establishment with the minimum necessary force. Opponents would be defeated by means of confusion and disorientation rather than carnage. No more resources should be expended, assets ruined or blood shed than absolutely necessary to achieve specified political goals.

If wars had to be fought, this was the way to do it. There was a particular appeal here for the United States and its allies. High-quality weaponry reduced the importance of numbers while putting a premium on highquality troops. Now that bomb aim could be accurate, war aims could also be more precise. The key thing, however, was that these qualitative advantages were embedded in a massive material advantage.

The problem with this vision was not that it was technically out of reach. By and large, the weapons performed as advertised. The problem lay in the nature of the conflicts. The Americans always understood that there were high risks in becoming drawn into fighting insurgencies, as they had done in Vietnam. This explains their reluctance to get involved in lesser operations that had little to do with what they considered to be proper warfare against serious military powers. A brief and unsuccessful peacekeeping operation in Beirut in the early 1980s reinforced the lessons of Vietnam. It left no appetite for becoming involved in distant civil wars. Even without a Warsaw Pact to worry about, the focus remained on highintensity conflicts against delinquent states. There was scant interest in low-intensity interventions to keep squabbling populations apart, a task 
recognised as likely to be both thankless and enduring. The focus and preparations were on decisive battles against other great powers-so-called peer competitors.

Yet the wars of the first decade of the 21 st century came in response to an attack not from a revived Russia or an ascendant China but from the far end of the spectrum of threats. The most shocking perpetrator was not a powerful state but a terrorist group based in one of the poorest countries in the world. Al Qaeda organised an audacious attack against the symbols of US power. The attack employed one of the world's oldest weaponsknives-to hijack commercial airliners and turn them into deadly instruments of slaughter. Suddenly all the issues connected with 'weak', 'failing', 'fractured' or 'rogue' states acquired a harder edge. The response took the form of interventions that were not presented as discretionary nor, initially, as humanitarian in purpose. They were justified by the demands of national security.

Both the Afghan and Iraqi regimes were toppled by an unremitting display of US military capability. But, in both cases, this was followed by fury and frustration as it proved to be impossible for US forces to resolve bitter internal divisions.

Unfortunately, toppling regimes meant that they had to be replaced, lest elements of the old regime return. The short, sharp wars were followed by long, gruelling and inconclusive counter-insurgency campaigns. These required establishing security and setting these countries on their paths to reconstruction. This was easier said than done. The idea was to hand over to local forces to keep security on behalf of a local government, but this was continually delayed. Then, when it was eventually thought safe to leave, it turned out not to be the case. The insurgencies returned in more virulent forms. There had been a failure to grasp the challenges that would be faced reconstructing a deeply divided and brutalised society and helping its people settle on a new form of government. The transition from an invading force to an occupying administration was poorly handled. The military and political dimensions could not be treated separately.

These forms of warfare were the opposite of the ideal types of classical warfare. Instead of relatively civilised combat professionally conducted by high-quality regular forces, the struggle was against murky, subversive forms of terrorism and militias. Instead of directing fire with precision against targets of evident military value, they faced opponents whose 
strategies depended on maximising their enemies' pain. The harsh reality was of conflicts that were prolonged, doleful and disappointing. Old enemies refused to go away and new ones emerged, dragging the Americans and their allies into a continual, relentless war against opponents that for the most part preferred to remain hidden and, in many cases, were prepared to accept a martyr's death as human bombs. All the clichés of guerrilla warfare, dimly remembered from the 1960s, of an enemy hiding in the shadows and the tactics of darting flea bites, returned. The lessons of Vietnam had to be relearned, so US forces adapted to the demands of counter-insurgency and began to work out what it took to contain, if not quite defeat, their new foes.

These conflicts exposed flaws with the revived classical model as an ideal type. The technological advances came from the West, and only wealthy countries could afford the weapons. This meant that opponents could not fight on Western terms. This problem was identified early on as 'asymmetric warfare', capturing the theme that not everyone would or could fight in the same way. But it did not quite capture the extent to which those in weaker positions had no interest in keeping war apart from society. Their incentives were to use their own societies as sanctuaries and their opponents' societies as targets.

The ideal type involved a vision for land warfare that involved light and agile formations not too encumbered by the need to carry their own firepower (because precision strikes could be called in from distant bases), and possessing knowledge of the battlespace to be able to avoid enemy traps and move swiftly into favourable positions. By contrast, counterinsurgency campaigns required forces to move among potentially hostile populations, accepting the risk from ambush and improvised explosive devices (IEDs). This required very different tactics from the management of large, disciplined forces under firm command and deployed as part of a larger plan.

Although the new technologies made it possible to choose targets to avoid populated areas and civilian infrastructure, they also made it possible to choose targets with exactly the opposite intention: to put more rather than fewer non-combatant lives at risk. Compare, for example, the Russian air campaign that devastated the city of Aleppo in Syria with the air campaigns of the United States and its allies. 
As a result of Iraq and Afghanistan, the Obama Administration became reluctant to get involved in more wars of this type, at least on the ground. It could justify anti-terrorism campaigns employing targeted killing using drones, but at most that helped contain a particular sort of threat. Only by bringing a degree of stability and security to the contested areas that provided the bases and recruits from such groups as ISIS and al Qaeda could the threat be truly degraded, let alone eliminated. Much can be achieved from the air, but it does not bring victory by itself. Wars are fought for political influence and control. That requires holding territory and exercising authority within it. Either intervention forces had to use their own infantry or else they had to rely on indigenous forces, which often meant awkward compromises over political objectives and military methods.

Consider Russia as a country also engaged in conflicts beyond its borders and one that also is reluctant to commit substantial ground forces of its own. It was more effective in Syria where forces loyal to President Assad, along with those of Iran and Hezbollah, provided sufficient ground forces. In Eastern Ukraine, by contrast, although Russia provided considerable material support plus Special Forces, the separatists remained hemmed into much of their original area after September 2014.

These wars rarely involve battles. There might be rushes of activity as one force is pushed out of a presumed stronghold, with frightened people scampering away after their supposed protectors have fled. At other times, the fighting might be marked by sporadic bursts of artillery and IEDs but otherwise little of note happening for weeks and months. Then some spark, perhaps a new atrocity or food shortages or a change in the weather, leads to another bout of killing and more pleas to desist. Protest movements morph into militias and then militias morph into criminal gangs or into rival factions, fighting each other with the same ferocity that they once fought their shared enemy. This is one reason why it is hard to bring conflicts to a definitive conclusion. For many of those involved in local militias, there are too many opportunities connected with trafficking in drugs, minerals, people and guns to allow a profitable activity to come to an end.

Nor were the militias and terrorists innocent of the new technologies. Their smart phones provided many of the new capabilities that made the RMA possible, offering access to vast stores of knowledge on an infinite number of topics, imagery of local terrain, navigation and instantaneous 
communications. They could also often gain access to modern weaponry, whether from patrons and dealers or picked up from government forces that had fled rather than fought. Artillery and small arms were readily available. Sometimes portable anti-air weapons and even tanks could be found. There was always the possibility of improvisation-for example, by sticking machine guns onto the top of trucks. Of course, irregular forces lacked the training and discipline of the best regular forces, but they could improve over time. Their vulnerability was to air power. They could be spotted and destroyed if they moved out into the open.

The success of counter-insurgency campaigns could not be measured by victories in battle, but by the authority of the government or whatever political force was being backed. The critical effects were not those an armed force had on another, but those it had on the adversary's political and social structures. From this came a view that a key feature of modern conflict lay in the ability to shape public opinion, about whether opponents could cope and who would prevail and whether there would be much to benefit ordinary people either way. This led to talk of narratives and information operations as being no less essential to success than more traditional forms of kinetic activity.

The problem with this lay not in the appreciation of the importance of prevailing perceptions of a conflict but in the ability to influence those perceptions and the potential consequences of the changed perceptions. The problem for those who sought to control the perceptions of others was that they could rarely control the totality of communications from their 'side'. The most eloquent messages are often unintended, resulting from either the actions of careless troops or the policy statements of careless politicians. Reactions to being treated harshly and disdainfully for no good reason, especially by uninvited foreign troops, were not likely to vary greatly among otherwise diverse cultures. It would take more than a keen and well-resourced public affairs outfit putting a positive 'spin' on events to repair the damage in the aftermath of such behaviour. Most importantly, it would require evidence that policies had been changed and that more appropriate behaviour could be expected in future. Even if perceptions changed, there was not necessarily much that could be done with a different point of view. It did make a difference if a population yielded fewer recruits, sanctuaries, resources and intelligence to the enemy, but the key determinant of that was who actually was best placed 
to provide security and shape behaviour on the ground. These 'perception wars' were products of the material conditions they were supposed to shape.

This can be seen with the Russian experience of using disinformation as an instrument of strategy. Thus, in Ukraine, they did not wish to admit the role their forces were actually playing as this would have required acknowledging aggression. The pretence therefore was that the individuals concerned were volunteers or on holiday. When one of their anti-aircraft missiles shot down a Malaysia Airlines aircraft in July 2014, instead of accepting responsibility, they sought to suggest that it was the Ukrainians, with the claims becoming ever more fanciful. As this pattern of behaviour became apparent, Russian officials were not believed about anything, even when telling the truth. Russian propaganda played well in Russia but badly everywhere else, which had the effect of increasing Russia's sense of isolation but not of its influence.

The Russian strategy in Ukraine was characterised as a deliberate and skilful application of 'hybrid warfare'. This term gained currency after Israel was caught out during the Lebanon War of 2006 by the combination of guerrilla and conventional tactics adopted by Hezbollah. It came to refer to an approach drawing upon instruments from across the full spectrum, including terrorism, insurgency, criminality and conventional operations along with the extensive use of information operations. As an approach, this is not simple as it requires a formidable command structure to pull together these various instruments to achieve the greatest strategic effect. In practice, it might refer to a number of separate efforts set in motion at the same time that might or might not reinforce each other. In Ukraine, complex command arrangements complicated Russian attempts to control the situation on the ground while efforts at deception were by and large ineffectual as they became progressively transparent. One possible success was in projecting a more menacing image than Russia's actual strength warranted, which served to deter the West from escalating the conflict.

In practice, these forms of warfare acknowledged the limitations of the classical model in contemporary circumstances. Because of the difficulty of imagining a truly decisive military campaign under contemporary circumstances, it had been necessary to look for shortcuts and alternatives. Instead of the knockout blow in a decisive battle, various forms of force and coercion were used to reshape conflicts. Within these conflicts, the 
balance of advantage might shift one way or the other, but it was difficult to bring them to a conclusion. Success required exceptional circumstances when either the first moves were decisive because the defeated party had been caught napping or else because the participants were exhausted and there was a genuine basis for a political settlement.

The wars fought by Western countries in Afghanistan and Iraq turned out to be frustrating and inconclusive. The wars that were not fought, however, would have been much, much worse. One benign interpretation of all this is that the appreciation of the limits the classical model has extended the arena of deterrence. When it comes to war involving great powers, there is an argument that the cautions induced by nuclear deterrence now extend to conventional conflicts as well. It may be-as with Russia taking on Ukraine and Georgia but not Estonia and Latvia—that the unique dangers involved in any sort of major power are sufficient to reduce risk taking. This is why military action by those revisionist powers that do have grievances that they would like to address tend to be geared to probing, exploring the limits of acceptable behaviour rather than bold offensives designed to take a large opponent out action.

It is possible to frustrate, deflect, divert and distract opponents with a variety of forms of coercion, including economic sanctions, cyber attacks and some forms of deadly force, including seizures of disputed territory. None of this constitutes true victory. Has Putin won or lost in Ukraine or even in Syria? The fact that we can even have this debate indicates that the outcomes of war lack the clarity of the victories sought in the past, those with ceremonial surrenders and an enemy state at your mercy.

The challenge for the West in all of this is that wars have come to lack borders and endpoints. The idea of conflict as something contained in time and space, where there is a sharp demarcation between peace and war and between the civilian and military spheres, is consistently undermined. The classical model of warfare, of decisive campaigns, remains a beguiling ideal, but the real challenge for Western strategists is to come to terms with wars of continuing political struggle where military action ensuring a satisfactory political outcome have proved elusive. 
This text is taken from New Directions in Strategic Thinking 2.0:

ANU Strategic \& Defence Studies Centre's Golden Anniversary

Conference Proceedings, edited by Dr Russell W. Glenn, published 2018 by ANU Press, The Australian National University, Canberra, Australia. 